\title{
Consideration on online education in Romania
}

\author{
Janusz Grabara ${ }^{1}$, Petre Bosun ${ }^{2, *}$ \\ ${ }^{1}$ Czestochowa University of Technology, gen. Jana Henryka Dąbrowskiego 69, Częstochowa, Poland \\ 2University of Timişoara, Vasile Pârvan 2, 300223, Timişoara, Romania \\ ${ }^{*}$ E-mail address: bosunpetre@yahoo.com
}

\begin{abstract}
Using the online learning platform provides a dynamic training program at substantially reduced costs compared with the conventional systems. They ensure the development of a scalable products, secure online access to thousands of students even for distance learning, offering them the books available online, multimedia support, etc.. Outside the curriculum it was developed a flexible verification and scoring system, uploading projects, maintaining a permanent online contact between students on the one side and between students and lecturers on the other side. In the online lessons there may be audio or video links between students and lecturer, when the session administrator believes that certain aspects need to be developed in this way. Ensuring for a convenient program of resources access may allow students to structure better the learning period.
\end{abstract}

Keywords: globalization; Global Governance; online education; LMS System; CMS System

\section{INTRODUCTION}

At a time when the internet access becomes easier, and students are increasingly attracted to virtual space, developing an online education system can combine the need for young people knew and the desire to spend more time on the computer. Adding a proper multimedia support can make a course attractive enough so that the rate of assimilation of new concepts can be far superior to traditional courses. The development of online education systems may be minimal compromise between the need for knowledge and lack of time for study.

\section{ONLINE EDUCATION IN ROMANIA}

Online Education is a modern process, but unfortunately not always properly understood even by the providers of such education models. Often online education is minimized to simple online presentation of learning materials and possibly short online tests (Bates, 2000; Traisatru, 2013; Cotoc, Traistaru, 2013).

There are unfortunately even universities that claim with online modules for a range of disciplines, but presents only curriculum that students can download and read later "when they have time." Of course, this is a step forward but a system for online education involves a more serious approach. 
This small step is made in the direction of the curricula management, but requires standardization for the educational online system in its own manner of each unit in addition to respect standards that the original pattern of each unit can assure a faster assimilation uptake by students.

They do not have to discover for each discipline the logic of presentation of each course (Borowski, 2013; Avram, Traistaru, 2014). Curricula management should be similar to various courses so that students should be concerned only with the substance of the course and not with the forms of different presentation from a course or another. This fact involves a comprehensive integration of their curriculum in the school system.

Management education system curriculum should require management standard a series of directives to be followed, of course, for elements of originality in the different materials that lend themselves to particular approaches (Brint, 2006; Vlăduţescu, 2013).

A simple model of all courses may require common standard such as blocking access to some part of the course for students who havn't passed a series of tests, had no projects, or are not participating in online forums of discussion for the discipline. Another element is that some modules could integrate some video presentation and factors of production directly involved in practical problems can be invited for some practical explanations for the theoretical course.

Also from time to time or even permanently online video seminars may be held. Last but not least small groups of students can be present simultaneously for the development of mini online projects, supervised by an assistant (Borowski, 2014; Drămnescu, 2013). These could be just some of the items you need to define the educational system and in particular the curriculum management.

The simple presence of the online courses and tests that can be supported by students "anytime" is inappropriate unless it provides a permanent connection between students and the educational system.

There are certainly shy students, students who work part time or full time, there are students, who do nothing all day but can not find time to learn. The system does not have to leave the option to postpone indefinitely a test project etc. (Ferrer, Minguillón, 2011; Smarandache, Vlăduţescu, 2013; Smarandache, Vlăduţescu, 2014).

The great advantage of learning "anytime students have time" which boasts a series of online educational institutions represent a big danger threatening the future of online education. With his functions of organization and control, the educational management must manage very discreetly, but firmly the time dedicated to study by his students.

Can be used a number of constraints outside those specified, such period for submission of projects to be extremely tight, supporting tests should be done in one day, in a narrow interval of time so that the same student is not able to support a test for another student, etc.

The presence of students must be permanent and active throughout the course, or it cannot be achieved without a proper educational management.

Although definitely have a cost lower than traditional courses, online education has its financial costs and there is an important cost management system to determine the usefulness of acquisition (dedicated servers, broadcasting systems - video presentations, etc.).

\section{LMS, CMS SYSTEMS}

Online learning platforms are software, mostly free, available to users who support the presentation of curriculum, tests, etc. necessary for the study. Known as Learning Management System or Content Management System (there are other names and abbreviations) they can 
manage only broad management or management curriculum of the educational system, providing tools for development and presentation of course content. Ultimately the two concepts begin to interpenetrate and there is still some debate on integration in LMS or CMS system.

Extensive use of materials universally accepted (file type doc, pdf, xls, Flash, etc.). determine this concept not to be so important. (Hillar, 2011).

We will present some details about the Moodle platform (other platforms used are Claroline, ATutor, TCExam, DoceboLMS, Omeka etc.).

First it should be noted that there are no restrictions on the operating system. Moodle runs without modification on Unix, Linux, FreeBSD, Windows, Mac OS X, NetWare and any other system that supports PHP and a database.

Moodle has many features considered typical for an educational platform plus some original innovations (such as its filtering system). Moodle is very similar to a learning management system. Moodle can be used in many areas such as: in education, training and development, business environment (Stocker, 2011; Stavre, 2012; Bărbulescu, 2013).

Developers can extend the platform's modular construction Moodle by creating new plugins that have specific functions - types of resources, types of questions (multiple choice, true or false, "fill space", etc..) Graphical themes, methods authentication (may require username and password access), application methods, content filters, quizzes or quiz questions, import / export in a number of formats: GIFT (format of Moodle), IMS QTI, XML or XHTML.

Moodle allows different kinds of questions: calculations, descriptions, essays, match answers built multiple choice, short answers, numeric answers, short answers matching randomly placed, true / false.

\section{COURSE IMPLEMENTATION}

We briefly present the options in a course implementation.

\section{A. Establishing the general format of the course}

Initially it will be mentioned the category of the course (ie. Management III year), the title of the course, course format (weekly, social, SCORM, etc..), duration, start date of the course.

You can set also some details of show or unshow marks obtained by students, the presentation of the hidden formats, if it's not a public display or an activity report, the maximum size of files that students can upload etc. (Dragotă, Dragotă, Țâţu, Țâțu, 2009; Enăchescu, 2013).

Also at the beginning students can form groups that will have some joint activities and determine how to access the course (free, password based, guest access). 


\section{Edit course settings}

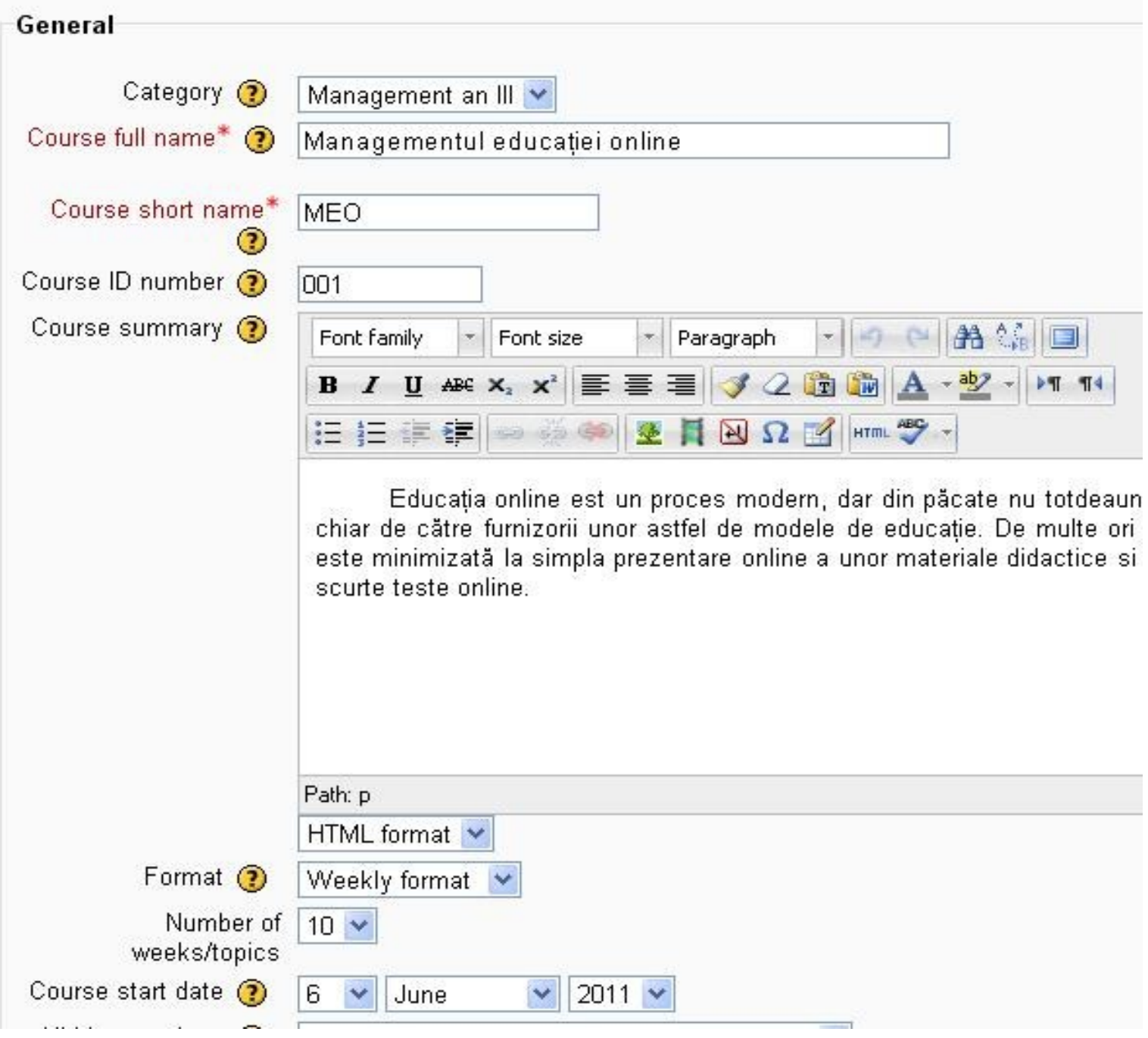

\section{B. Setting the course's activities and resources}

Each course can be added to a series of activities. We present some of the most important:

Assignments - they are completed by the student completely offline, themes that they upload to the site, receiving a note. They are required by the teacher and have established criteria for scoring.

Choices - used for a more consistent feedback, elections are asked by the class teacher. They can be displayed or can be known only to teachers and students who responded.

Journal - Each student may be attached to a journal, accessible only by student and instructor.

Lesson - The lessons are web pages, displayed in a given order based on student responses to certain questions. These questions are designed to test the degree to which the

\begin{tabular}{l} 
Add an activity.... \\
\hline Add an activity... \\
Assignments \\
Advanced uploading of files \\
Online text \\
Upload a single file \\
$\quad$ Offline activity \\
Chat \\
Choice \\
Database \\
Forum \\
Glossary \\
Lesson \\
Quiz \\
SCoRm package \\
Surey \\
Wiki \\
Workshop
\end{tabular}


material was understood. Correct answers enable the browsing of the next material while wrong answers conduct the student to intermediate pages. This branching, well-managed can be an extremely useful interesting scroll of the selecting materials only in the interest of the student. The instructor can determine if the student has a limited access to every page, if you can return to previous pages etc. There are also pages with options to jump to specific chapters.

Quiz - sets of questions that can be used even in other courses. You can create questions and define the categories of questions. It can be fixed on the test, the deadline to support the test, the test, the number of attempts allowed. The teacher can choose from a variety of types of questions with multiple answers, one correct answer, the short answer, numeric response, true or false, matching, embedded answers, etc.

Resources that can be attached to the course are files, directories, HTML, URL and represents course materials which can be a real help for students.

\begin{tabular}{l} 
Add a resource... \\
\hline Add a resource... \\
File \\
Folder \\
lMS content package \\
Label \\
Page \\
URL \\
\hline
\end{tabular}

\section{CONCLUSION}

Online education involves students, teacher, proper services and content. All these elements cannot be managed independently, since learning is a combination of these factors.

Trying to reproduce the traditional process of learning from teacher to student based on a producer consumer model (One to Many) is easily exceeded. The concept of learning itself has changed the focus to the interaction between student and curriculum, and from this point of view the online education systems have a considerable advantage.

\section{References}

[1] Armstrong L. (2007). Competing in the Global Higher Education Marketplace. New Directions for Higher Education. Wilez Production, Inc.

[2] Bates A. (2000). Managing technological change: Strategies for College and University leaders. San Francisco: Jossey-Bass.

[3] Lis T., Bajdor P. (2013). Sales Logistics as a Model Used by Companies Fulfilling Individual Customer's Needs. In: Challenges in Contemporary Management. Monograph. Scientific Editors Anna Lemańska-Majdzik, Piotr Tomski, Sekcja Wydaw. WZ PCzęst, Czestochowa.

[4] A. Borowski, International Letters of Social and Humanistic Sciences 11 (2014) 1-168.

[5] Ş. Vlăduţescu, E. M. Ciupercă (2013). Next Flood Level of Communication: Social Networks. Aachen: Shaker Verlag.

[6] Brint S. (2006). Schools and societies. CA: Stanford University Press. (6). Ş. Vlăduţescu.

[7] N. Ferrer, J. Minguillón (2011). Content management for E-learning. New York, Springer.

[8] S. Hillar (2011). Moodle 2.0 Multimedia Cookbook, Packt Publishing. 
[9] S. Marginson, M. Van Der Wende (2007). Globalisation and Higher Education, OECD, Paris.

[10] V. L. Stocker (2011). Science Teaching with Moodle 2.0. Packt Publishing.

[11] D. Ţâţu, R. Bărbulescu, Theoretical and Applied Economics 11(516) (supplement) (vol2)) (2007) 189-192.

[12] Ştefan Vlăduţescu, European Scientific Journal 9(32) (2013).

[13] A. Borowski, International Letters of Social and Humanistic Sciences 3 (2013) 69-74.

[14] Aurelia Traistaru, Elena Antoanela Cotoc (2013). Archiving, Keeping Records and Financial Accounting Documents. International

[15] O. Arhip, C. Arhip (2012). Beyond 'Customer is King”: Sales and Marketing Promotion. International Conference on Business Excellence 2007.

[16] Vladimir-Aurelian Enachescu, Journal of Community Positive Practices 13(2) (2013).

[17] Dan Ionescu, Cristina Pretorian, International Letters of Social and Humanistic Sciences 9 (2014) 49-56.

[18] M. Suarez-Orozco, D. B. Qin-Hillard (2004). Globalization: Culture and education in the new millenium. University of California Press.

[19] Maria Nowicka-Scowron, Ioan Constantin Dima, Ştefan Vlăduţescu (2012). The IC concept in the Strategies of Developing in the Urban and Regional Communication Networks. International.

[20] Janusz Grabara, Michal Kolcun, Sebastian Kot (2014). The Role of Information Systems in Transport Logistics. International.

[21] Ioan Constantin Dima, Mariana Man (2013). Budgeting and Management Control in Industrial Companies. Saarbrucken: LAP Lambert Academic Publishing.

[22] V. A. Enachescu, D. A. Hristache, C. E. Paicu, Review of Applied Socio-Economic Research 4(2) (2012) 93-96.

[23] M. Siminică, A. Traistaru, International Journal of Education and Research 1(12) 2013.

[24] Aurelia Traistaru (2013). The components of economic record and the research object of Accounting. European.

[25] Ioan Constantin Dima, Ştefan Vlăduţescu (2012). Persuasion elements used in logistical negotiation: Persuasive logistical negotiation. Saarbrucken: LAP Lambert Academic Publishing.

[26] F. Smarandache, Ş. Vlăduţescu (2014). Neutrosophic Emergences and Incidences in Communication and Information. Saarbrucken: LAP Lambert Academic Publishing.

[27] M. G. Mangra, E. A. Cotoc, A. Traistaru, Journal of Studies in Social Sciences 6(1) (2013).

[28] M. G. Păun, International Letters of Social and Humanistic Sciences 06 (2014) 42-48.

[29] Ştefan Vlăduţescu (2013). What Kind of Communication Is Philosophy. Jokull.

[30] A. Borowski, International Letters of Social and Humanistic Sciences 4 (2013) 70-74.

[31] J. Tittenbrun, International Letters of Social and Humanistic Sciences 2 (2014) 20-40. 
[32] I. C. Dima, M. Man, Ş. Vlăduţescu (2012). The Company's Logistic Activity in the Conditions of Current Globalisation. In H. Cuadra-Montiel (Ed.), Globalization, Education and Management Agendas (pp. 263-294). Rijeka: Intech.

[33] F. Smarandache, Ş. Vlăduţescu, (2013). Communication vs. Information, a Neutrosophic Solution. Neutrosophic Sets and Systems.

[34] Ion Stavre (2012). Internet and digital technology - influences on audiovisual communication and on teaching at master's degree level, Valencia, 2012, Published by International Association of Technology, Education and Development - ISBN: 978-84-615-5563-5.

[35] Marioara Avram, Aurelia Traistaru, International Letters of Social and Humanistic Sciences 13 (2014) 79-88.

[36] Răzvan Bărbulescu, Romanian Economic Business Review 8(1) (2013) 66-72.

[37] Ştefan Vlăduţescu (2014). Eight computational-communicative operations of building information. Mitteilungen Klosterneuburg.

[38] A. Borowski, International Letters of Social and Humanistic Sciences 2 (2014) 110-121.

[39] Răzvan Bărbulescu, Romanian Economic Journal 13(36) (2010). .

[40] I. C. Dima (2013). Industrial Production Management in Flexible Manufacturing Systems. IGI Global SUA.

[41] V. Dragotă, M. Dragotă, L. Obreja, L. Țâţ̧u, A. Ciobanu, A. Racşa (2005). Abordări practice în finanţele firmei. Editura Irecson, Bucureşti.

[42] A. Borowski, International Letters of Social and Humanistic Sciences 6 (2013) 86-90.

[43] Ştefan Vlăduţescu (2013). Principle of the Irrepressible Emergence of the Message. Jokull.

[44] O. Arhip (2012). Characteristics of Meta-Referential Discourse. Philologica Jassyensia.

[45] Jason L. Powell, International Letters of Social and Humanistic Sciences 7 (2014) 22-30.

[46] Bianca Teodorescu, International Letters of Social and Humanistic Sciences 12 (2014) 73-78.

[47] M. Dragotă, V. Dragotă, L. Ţâţu, D. Ţâţu, Romanian Journal of Economic Forecasting 1 (2009) 76-93.

[48] Aurelia Traistaru, Jokull 63(9) 2013 125-135.

[49] Ştefan Vlăduţescu, International Letters of Social and Humanistic Sciences 10(2) (2014) 100-106.

[50] Alina Ţenescu (2009). Comunicare, sens, discurs. Craiova: Editura Universitaria. 